G. G. Pivnyak, Acad. of the NAS of Ukraine,

Dnipro University of Technology, Dnipro, Ukraine, e-mail:

Dr. Sc. (Tech.), Prof., orcid.org/0000-0002-8462-2995,

O. O. Beshta,

orcid.org/0000-0001-6397-3262

\title{
A COMPLEX SOURCE OF ELECTRICAL ENERGY FOR THREE-PHASE CURRENT BASED ON A STAND-ALONE VOLTAGE INVERTER
}

Purpose. To substantiate the operability of a combined power source of asynchronous electric drive of a vehicle, consisting of two power sources and one autonomous voltage inverter, to establish operating modes using zero combinations of inverter keys and to formulate a condition for energy transfer to an electromechanical converter from an additional power source.

Methodology. In the study on the work of an autonomous voltage inverter with two power sources, methods of mathematical and simulation modeling were used. To select the optimal method for implementing the control algorithm, a comparative analysis method and an analysis of a symmetric power system were applied.

Findings. The efficiency of the asynchronous motor power system from one autonomous voltage inverter with two power sources is proved. The paper presents mathematical calculations for constructing an electromechanical circuit, a modified algorithm for switching the keys of an inverter of a combined power source is given; physical processes are described.

Originality. The conditions of energy transfer to the electromechanical converter from an additional power source are formulated, which are provided by the choice of the load circuit parameters of the EMF of the additional source and increase the voltage component and the load capacity of the electromechanical converter.

Practical value. The electromechanical circuit of the vehicle's asynchronous electric drive has been simplified due to the combined power supply, consisting of two power supplies and one autonomous voltage inverter. One of the sources is an additional source that is connected to the electric motor through the connection circuit to the zero point of the stator motor windings and the "negative" terminal of the autonomous voltage inverter and includes a DC-DC inverter, diode, inductor and discharge resistor.

Keywords: autonomous voltage inverter, direct current sources, electric drive

Introduction. Currently, the integration of several sources of electrical energy into an electromechanical system is not new. Two or more sources can be used for uninterrupted power supply of an electric energy consumer. In such hybrid systems, the disadvantages of one energy source are mitigated by the advantages of another and vice versa. For example, some sources provide peak power, while others focus on sustainable operation. To ensure the effective joint use of two sources of electrical energy of various types in one electromechanical system is the task of this article.

Results. Consider a three-phase stand-alone voltage inverter powered by two DC sources with EMF $E_{1}$ and $E_{0}$ and assume $E_{1}>E_{0}$. The source EMF $E_{0}$ is connected to the threephase consumer (primary circuit of the induction motor) through the inductance $L_{0}$, the current limiting resistor $R_{0}$ and the diode VD to zero point " 0 " (Fig. 1) [1, 2].

The three-phase consumer system is symmetric for complex phase resistances

$$
\dot{Z}_{f}=R_{f}+j \omega_{1} L_{f},
$$

where $R_{f}$ is active phase resistance; $L_{f}$ is phase inductance; $\omega_{1}$ is angular frequency of the power supply.

To create a three-phase symmetric system of voltages in the windings of the consumer, it is necessary to form a rotating magnetic field. The following algorithm with a minimal number of switching and zero-state for keys must be provided for the $E_{1}$ source:

$$
\begin{aligned}
& 1^{\text {st }} \text { sector: } 000 \rightarrow 100 \rightarrow 110 \rightarrow 111 \rightarrow 110 \rightarrow 100 \rightarrow \\
& 2^{\text {nd }} \text { sector: } 000 \rightarrow 010 \rightarrow 110 \rightarrow 111 \rightarrow 110 \rightarrow 010 \rightarrow \\
& 3^{\text {rd }} \text { sector: } 000 \rightarrow 010 \rightarrow 011 \rightarrow 111 \rightarrow 011 \rightarrow 001 \rightarrow \\
& 4^{\text {th }} \text { sector: } 000 \rightarrow 001 \rightarrow 101 \rightarrow 111 \rightarrow 101 \rightarrow 001 \rightarrow \\
& 5^{\text {th }} \text { sector: } 000 \rightarrow 001 \rightarrow 101 \rightarrow 11 \rightarrow 101 \rightarrow 001 \rightarrow \\
& 6^{\text {th }} \text { sector: } 000 \rightarrow 100 \rightarrow 101 \rightarrow 111 \rightarrow 101 \rightarrow 001 \rightarrow 000 .
\end{aligned}
$$

It is obvious that the sector switching of the invertor transistors gives a stepped voltage curve. To obtain sinusoidal phase voltage

(C) Pivnyak G. G., Beshta O. O., 2020

$$
\begin{gathered}
V_{A}=V_{m} \cos \omega_{1} t ; \quad V_{B}=V_{m} \cos \left(\omega_{1} t-\frac{2 \pi}{3}\right) ; \\
V_{C}=V_{m} \cos \left(\omega_{1} t-\frac{4 \pi}{3}\right),
\end{gathered}
$$

it is necessary to form a vector of voltage $V_{1}$ in the space of coordinates $(\alpha, \beta)$, aligned with the $\alpha$ axis with the phase A axis (Fig. 2), of the form

$$
\overline{V_{1}}=2 / 3\left(V_{A}+\underline{a} V_{B}+\underline{a}^{2} V_{C}\right),
$$

where $\underline{a}=e^{j \frac{2 \pi}{3}} ; \underline{a}^{2}=e^{j \frac{4 \pi}{3}} ; V_{m}$ is the phase voltage amplitude.

The space-time vector in exponential form $V_{1}$ will look like

$$
\overline{V_{1}}=\left|\overline{V_{1}}\right| e^{j \theta}
$$

where $\theta=\omega_{1} t ;\left|\bar{V}_{1}\right|=\frac{3}{2} V_{m}$.

Since the vector $\bar{V}_{1}$ can be projected on the axis $\alpha$ and $\beta$ of the coordinate system $(\alpha, \beta)$, it can be represented as

$$
\overline{V_{1}}=V_{1 \alpha}+j V_{1 \beta},
$$

where $V_{1 \alpha}, V_{1 \beta}$ are the projections of the vector $\bar{V}_{1}$ on the axis $\alpha$ and $\beta$ respectively.

That is

$$
\begin{aligned}
& V_{1 \alpha}=V_{m} \cos \theta ; \\
& V_{1 \beta}=V_{m} \sin \theta .
\end{aligned}
$$

Thus, for the angle $\theta_{i}=\omega_{1} t_{i}$ the position of the vector $V_{1}$ will be determined by its projections $V_{1 \alpha, i}$ and $V_{1 \beta, i}$. Accordingly, for the angle $\theta_{i+1}=\omega_{1}\left(t_{i}+\Delta t\right)$ these will be the projections $V_{1 \alpha, i+1}$ and $V_{1 \beta, i+1}$.

If we consider the position of the vector $V_{1}$ between these two states, then its projections on the $\alpha$ and $\beta$ axis for the current intermediate position $\theta_{i}<\theta<\theta_{i+1}$ can be described by the equations [3] 


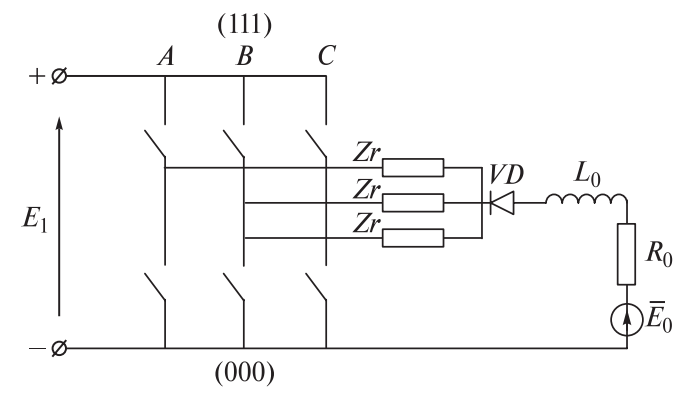

Fig. 1. Combined power supply:

$E_{1}, E_{0}$ - power supplies; $L_{0}-$ inductance; $R_{0}$ - limiting resistor; VD-diode

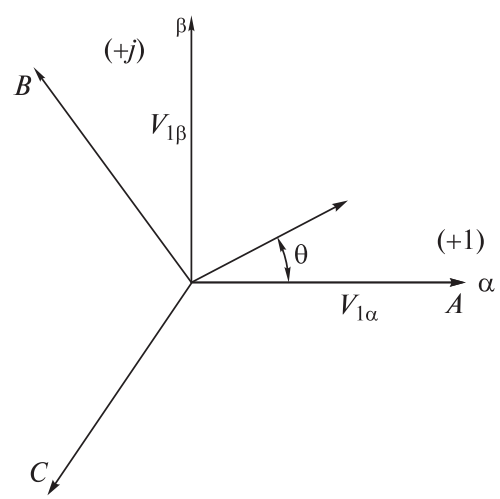

Fig. 2. Formation of voltage vector $\overline{V_{1}}$ :

$V_{1 \alpha}, V_{1 \beta}$ are projections of the vector; $\bar{V}_{1}, \theta$ is the angle of the vector $\overline{V_{1}} ; \alpha$ and $\beta$ are the axes of the coordinate system

$$
\begin{aligned}
& V_{1 \alpha}=V_{1 \alpha, i} \tau_{1}+V_{1 \alpha, i+1} \tau_{2} ; \\
& V_{1 \beta}=V_{1 \beta, i} \tau_{1}+V_{1 \beta, i+1} \tau_{2},
\end{aligned}
$$

where $\tau_{1}=t_{1} / T_{s}$ is the relative residence time of the vector $\left(\bar{V}_{1}\right.$ in the angular position $\theta_{i} ; \tau_{2}=t_{2} / T_{s}$ is the relative residence time of the vector $\bar{V}_{1}$ in the angular position $\theta_{i+1} ; T_{s}$ is the key switching time.

The sinusoidality condition for phase voltages is satisfied by matching equations (1) and (3), (2) and (4), from which the dependences $\tau_{1}(\theta)$ and $\tau_{2}(\theta)$ are obtained.

Consider now connecting another EMF source $E_{0}$ through the diode $V D$. Fig. 1 and the key switching algorithm show that the diode $V D$ will open in any case in the state $(000)$ of the invertor keys, since the phases of the three-phase consumer are connected to the minus of the source $E_{1}$, and the diode's anode will have a positive potential of the source $E_{0}$ [4].

In this case, the current flow pattern $I_{0}$ in the source circuit $E_{0}$ will look as shown in Fig. 3.

From Fig. 3 it is seen that there is a condition for the current $I_{0}$ to flow in the EMF circuit $E_{0}$ for any values of this EMF.

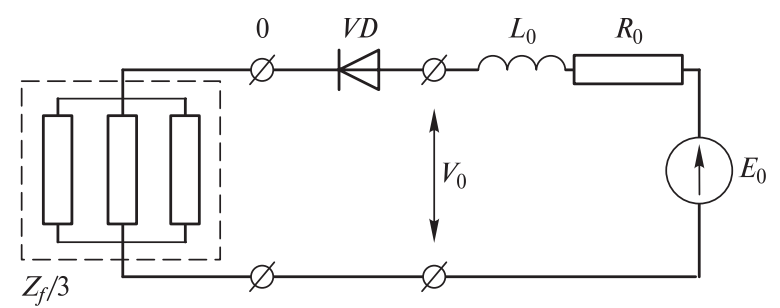

Fig. 3. Equivalent scheme of the current $I_{0}$ flow in the state (000) of the inverter keys (Legend - Fig. 1)
Thus, the state (000) of the keys of the autonomous voltage inverter is an unconditional combination for the formation of a closed current flow through the $V D$ diode and inductance $L_{0}$, which ensures the emergence of the EMF induction and voltage increase by the entire value, creating the conditions for opening the $V D$ diode for other combinations of keys and power consumer from two sources of energy.

There are switching periods of operation of the keys of an autonomous voltage inverter, which are essential for the operation of an integrated power source. Consider the possibility of increasing the open time of the diode $V D$ due to the influence of inductance $L_{0}$ and the resistance $R_{0}$ in the EMF circuit $E_{0}$. This will provide an opportunity to increase the connection time of the source $E_{0}$ to the consumer.

The transient process equation for changing the current $I_{0}(t)$ from zero to maximum $I_{0 m}$ for time $t_{0}$ of the state of the keys (000) has the form

$$
E_{0}=\left(R_{0}+R f / 3\right) I_{0}(t)+\left(L_{0}+L f / 3\right) \frac{d I_{0}(t)}{d t} .
$$

Since the time $t_{0}$ of the keys state (000) is small, we can consider a linear increasing of the current $I_{0}(t)$ during this time. In this case, the current integral $I_{0}$ is estimated by the area of the triangle with the base $t_{0}$ and height $I_{0 m}$. Then, after integrating equation (5) within the time $t_{0}$, we have

$$
E_{0}=\left(R_{0}+R f / 3\right) I_{\text {om }} / 2+\left(L_{0}+L f / 3\right) I_{\text {om }} / t_{0} \text {. }
$$

Therefore

$$
I_{\text {om }}=\frac{E_{0} t_{0}}{\left(R_{0}+R_{f} / 3\right) t_{0} / 2+\left(L_{0}+L_{f} / 3\right)} .
$$

We mean that the time of the zero state $(000)$ and the zero state (111) are equal, and also

$$
T_{s}=\tau_{1}+\tau_{2}+\tau_{0},
$$

where $\tau_{0}=2 t_{0} / T_{s}$.

By the end of time $t_{0}$, the voltage at the anode of the diode $V D$ will be

$$
V_{0}\left(t_{0}^{(-)}\right)=E_{0}-L_{0} \frac{I_{0 m}}{t_{0}}-I_{0 m} R_{0}
$$

At the moment of transition of the inverter from state (000) to state (100), the phase A of the consumer at the source $E_{1}$ is switched and the load changes abruptly (Fig. 4) [5].

In this case, the voltage $V_{10}$ from the source side $E_{1}$ is applied to the cathode of the diode $V D$. The energy accumulated in the inductance $L_{0}$ is spent on maintaining the decreasing current $I_{0}$. At this point in time, the voltage at the anode will be equal to

$$
V_{0}\left(t_{0}^{(+)}\right)=E_{0}+L_{0} \frac{I_{0 m}}{t_{0}}-I_{0 m} R_{0}
$$

The open state of the $V D$ diode will be provided by the inequality

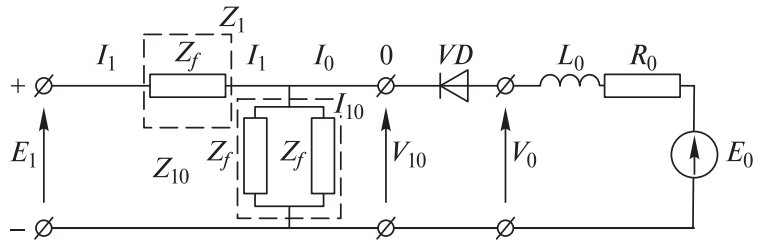

Fig. 4. Equivalent scheme of the current $I_{0}$ flow in the state (100) of the inverter keys (Legend - Fig. 1) 


$$
V_{0}\left(t_{0}^{(+)}\right) \geq V_{10}
$$

For the state of the switches (100), the phases of the consumer act as a voltage divider $E_{1}$ with levers $\frac{2}{3} E_{1}$ and $\frac{1}{3} E_{1}$ and resistances $Z_{1}$ and $Z_{10}$, respectively (Fig. 4). In the case of the state of the keys (110), the shoulders are reversed (Fig. 5).

Since the voltage shoulder $\frac{2}{3} E_{1}$ is maximum for all states of the inverter switches, we can assume that a constant transfer of energy to the consumer from the source $E_{0}$ is possible with the diode VD open, when $V_{10 \max } \geq \frac{2 E_{1}}{3}$. The minimum voltage level at the cathode of the diode VD should be $V_{10 \min } \geq \frac{E_{1}}{3}$ [6].

Since all nonzero states of the inverter switches are described by circuits (Fig. 4) and (Fig. 5), we represent these states in the form of a generalized circuit (Fig. 6) and use the loop current method to determine the parameters of the operating mode of the load from two power sources in each of states.

We proceed from the fact that in the circuit (Fig. 6) transient processes of current changes occur due to jump-like parametric disturbances.

In order to generalize, we consider a transient process in a circuit with an inductively active load for the time $\Delta t$ from the moment of a step change of the supply of a constant voltage $V$ with zero initial conditions $V(0)=0$ [7].

The transient process equation for a circuit has the form

$$
V(t)=I(t) R+L \frac{d I(t)}{d t} .
$$

The integral of the equation (8) in the interval $0-\Delta t$ is

$$
\int_{0}^{\Delta t} V(t) d t=R \int_{0}^{\Delta t} I(t) d t+L \int_{0}^{\Delta t} d I(t) .
$$

From the condition of a linear increase in the current (since $\Delta t$ is small), we have

$$
\int_{0}^{\Delta t} I(t) d t=I(\Delta t) \frac{\Delta t}{2} .
$$

Since $V(t)=$ const, we have $\int_{0}^{\Delta t} V(t) d t=V \Delta t$.

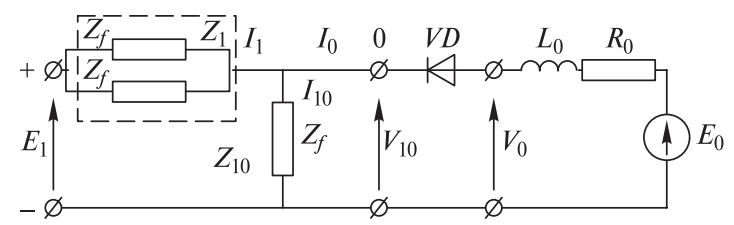

Fig. 5. Equivalent scheme of the current $I_{0}$ flow in the state (110) of the inverter keys (Legend - Fig. 1)

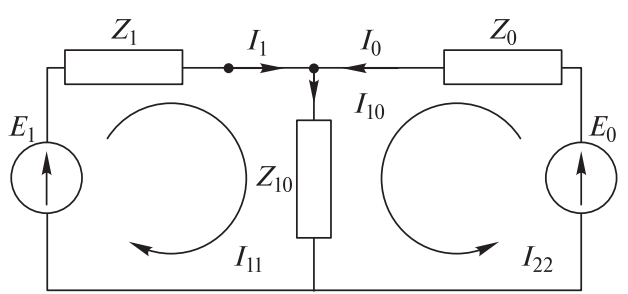

Fig. 6. Equivalent scheme of the inverter switches states (Legend - Fig. 1)
That is, equation (9) has the form

$$
V \Delta t=R \Delta I(\Delta t) \frac{\Delta t}{2}+L \Delta I(\Delta t),
$$

or

$$
V=I(\Delta t)\left(\frac{R}{2}+\frac{L}{\Delta t}\right)=I(\Delta t) Z(\Delta t)
$$

where $Z(\Delta t)$ is the equivalent load resistance in the transient.

Based on the above reasoning, we will present, according to equation (10), the resistance in the circuit (Fig. 6) for neighboring nonzero states of the inverter [8], for example, for the modes (100) and (110):

- mode 100

$$
\left.\begin{array}{l}
Z_{1}\left(t_{1}\right)=R_{f} / 2+L_{f} / t_{1} \\
Z_{0}\left(t_{1}\right)=R_{0} / 2+L_{0} / t_{1} \\
Z_{10}\left(t_{1}\right)=R_{f} / 4+L_{f} /\left(2 t_{1}\right)
\end{array}\right\} ;
$$

- mode 110

$$
\left.\begin{array}{l}
Z_{1}\left(t_{2}\right)=R_{f} / 4+L_{f} /\left(2 t_{2}\right) \\
Z_{0}\left(t_{2}\right)=R_{0} / 2+L_{0} / t_{2} \\
Z_{10}\left(t_{2}\right)=R_{f} / 2+L_{f} / t_{2}
\end{array}\right\} .
$$

Here, the time $t_{1}$ is the transition time in the mode (100); $t_{2}$ is the transient process time in the (110) mode.

According to the method of loop currents, we have (Fig. 6)

$$
\begin{aligned}
& E_{1}=I_{1}\left(Z_{1}+Z_{10}\right)+I_{0} Z_{10} ; \\
& E_{0}^{\prime}=I_{0}\left(Z_{0}+Z_{10}\right)+I_{1} Z_{10} .
\end{aligned}
$$

From equations (6) and (7) it follows

$$
\begin{gathered}
I_{1}=E_{1} \frac{Z_{0} Z_{10}}{D} ; \\
I_{0}=-E_{1}\left(\frac{E_{10}}{D}\right)+E_{0}^{\prime}\left(\frac{Z_{1}+Z_{10}}{D}\right) ; \\
I_{10}=I_{1}+I_{0}=E_{1}\left(\frac{Z_{0}}{D}\right)+E_{0}^{\prime} \frac{Z_{1}}{D},
\end{gathered}
$$

where $D=Z_{1} Z_{0}+Z_{0} Z_{10}+Z_{1} Z_{10}$.

It must be taken into account that $E_{0}^{\prime}$ includes the component $L_{0} \frac{I_{0 m}}{t_{0}}$, i.e.

$$
E_{0}^{\prime}=E_{0}+L_{0} I_{0 m} / t_{0} .
$$

Phase voltage in a 3-phase system is obtained by multiplying the currents $I_{1}$ and $I_{10}$ by the corresponding phase resistance, which vary depending on the state of the switches [9]. If we take the expression for currents and voltages in relative terms, then we get

$$
\begin{gathered}
z(\tau)=r / 2+1 / \tau ; \\
r=R / R_{b} ; l=L / L_{b} ; z(\tau)=Z(\tau) / Z_{b} ; \tau=t / T_{b} ;
\end{gathered}
$$

$R_{b}, L_{b}, Z_{b}, T_{b}$ - base values; $Z_{b}=R_{b} ; L_{b}=Z_{b} T_{b}$.

Then the currents by the formulas $(11-13)$ in relative units are equal to

$$
i_{1}(\tau)=e_{1}\left(\frac{z_{0}(\tau)+z_{10}(\tau)}{d(\tau)}\right) ;
$$




$$
\begin{gathered}
i_{0}(\tau)=-e_{1}\left(\frac{z_{10}(\tau)}{d(\tau)}\right)+e_{0}^{\prime}\left(\frac{z_{1}(\tau)+z_{10}(\tau)}{d(\tau)}\right) ; \\
i_{10}(\tau)=i_{1}(\tau)+i_{0}(\tau)=e_{1}\left(\frac{z_{0}(\tau)}{d(\tau)}\right)+e_{0}^{\prime}\left(\frac{z_{1}(\tau)}{d(\tau)}\right) ; \\
d(\tau)=z_{1}(\tau) z_{0}(\tau)+z_{0}(\tau) z_{10}(\tau)+z_{1}(\tau) z_{10}(\tau),
\end{gathered}
$$

where

$$
\begin{gathered}
e_{1}=E_{1} / E_{b} ; \quad e_{0}^{\prime}=E_{0}^{\prime} / E_{b} ; \quad z_{1}=Z_{1} / z_{b} ; \quad z_{10}=Z_{10} / z_{b} ; \\
z_{0}=Z_{0} / z_{b} ; i(\tau)=I(\tau) / I_{b} ; \quad I_{b}=E_{b} / Z_{b} ; \quad e_{0}^{\prime}=e_{0}+{ }_{0} i_{0 m} / \tau_{0},
\end{gathered}
$$

where $l_{0}=L_{0} / L_{b} ; i_{0 m}=I_{0 m} / I_{b} ; \tau_{0}=t_{0} / T_{b}$.

The voltage across the resistances $z_{1}(\tau), z_{10}(\tau), z_{0}(\tau)$ is defined as

$$
\begin{gathered}
\vartheta(\tau)=i_{1}(\tau) z_{1}(\tau) ; \quad \vartheta_{10}(\tau)=i_{10}(\tau) z_{10}(\tau) ; \\
\vartheta_{0}(\tau)=i_{0}(\tau) z_{0}(\tau) .
\end{gathered}
$$

We return to the 3-phase load system (Fig. 1) and consider the alternation of connecting the phases to the upper and lower shoulders of the inverter. When connecting one phase of the load to the upper arm, the resistance of this phase will be equal to

$$
z_{1}\left(\tau_{1}\right)=r_{f} / 2+l_{f} / \tau_{1},
$$

where $\tau_{1}$ is the relative connection time.

At the same time, two other phases are connected to the lower shoulder of the inverter and have a total resistance

$$
z_{10}\left(\tau_{1}\right)=z_{1}\left(\tau_{1}\right) / 2
$$

When switching the keys, a sequential step change in the phase resistances occurs. For example, from state (100), the inverter goes into state (110). In this case, phase B is connected to phase A connected to the upper arm of the inverter. Then, if the time spent in this state does not change, then the resistance of phase A changes to $Z_{10}\left(\tau_{1}\right)$, the resistance of phase B remains the same $Z_{10}\left(\tau_{1}\right)$, and the resistance of phase $\mathrm{C}$ changes to $Z_{10}\left(\tau_{1}\right)[10]$.

If we consider the intermediate resistance of the voltage vector between the two states (100) and (110), when the residence time of the vector in state (100) is $\tau_{1}$, and in state (110) $\tau_{2}$, then the voltage at the load phases will be determined as

$$
\begin{gathered}
\vartheta_{1 \mathrm{~A}}=\vartheta_{1}\left(\tau_{1}\right) \tau_{1}+\vartheta_{1}\left(\tau_{2}\right) \tau_{2} ; \\
\vartheta_{1 \mathrm{~B}}=-\vartheta_{10}\left(\tau_{1}\right) \tau_{1}-\vartheta_{1}\left(\tau_{2}\right) \tau_{2} ; \\
\vartheta_{1 \mathrm{C}}=-\vartheta_{10}\left(\tau_{1}\right) \tau_{1}+\vartheta_{10}\left(\tau_{2}\right) \tau_{2},
\end{gathered}
$$

where

$$
\begin{gathered}
\vartheta_{1}\left(\tau_{1}\right)=z_{1}\left(\tau_{1}\right) i_{1}\left(\tau_{1}\right) ; \\
\vartheta_{1}\left(\tau_{2}\right)=z_{1}\left(\tau_{2}\right) i_{1}\left(\tau_{2}\right) ; \\
\vartheta_{10}\left(\tau_{1}\right)=z_{10}\left(\tau_{1}\right) i_{10}\left(\tau_{1}\right) ; \\
\vartheta_{10}\left(\tau_{2}\right)=z_{10}\left(\tau_{2}\right) i_{10}\left(\tau_{2}\right) ; \\
z_{1}\left(\tau_{1}\right)=r_{f} / 2+L_{f} / \tau_{1} ; \\
z_{1}\left(\tau_{2}\right)=r_{f} / 4+L_{f} /\left(2 \tau_{2}\right) ; \\
z_{10}\left(\tau_{1}\right)=r_{f} / 4+L_{f} /\left(2 \tau_{1}\right)
\end{gathered}
$$

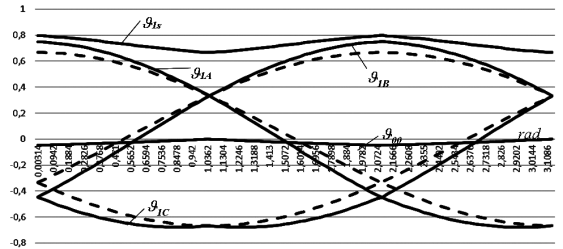

Fig. 7. The example of output voltage given by complex energy source:

$\vartheta_{1 \mathrm{~A}}, \vartheta_{1 \mathrm{~B}}, \vartheta_{1 \mathrm{C}}-$ voltage amplitude in phases A, B,C; $\left|\vartheta_{1}\right|-$ amplitude of the voltage vector of the complex source

Phase voltages in other sectors of the vector $\bar{V}_{1}$ are described in a similar way.

Thus, equations (14-17) allow us to obtain the average values of the inverter voltage for the period of time the keys are in a certain combination during the switching cycle, when the stand-alone voltage inverter operates from one power source.

If we take, for example, the following indicators of the system shown in (Fig. 1 ) relative units: $e_{1}=1 ; e_{0}=0.3 ; r_{f}=1 ; l_{f}=1$; $r_{0}=1 ; l_{0}=1$, then for an alternating voltage of a given frequency with an amplitude $\vartheta_{m}=0.667$, we will have a picture of the stresses shown in (Fig. 7).

Conclusions. We can say that the proposed generalized scheme, which consists of a complex source of direct current EMF (Fig. 1), is theoretically operable, makes it possible to calculate the general parameters of the mode of this source and increases the energy flow to the consumer.

Analysis of the combinations of inverter keys showed that to ensure the correct supply of energy to the consumer, it is necessary to use zero combinations of keys of the autonomous voltage inverter in a certain sequence.

In Fig. 7, the dashed lines represent the symmetric phase voltage system. Fig. 7 shows that the amplitude $\left|\vartheta_{1}\right|$ of the supply voltage vector of the combined source increases the amplitude and acquires a variable component $\vartheta_{00}$.

The amplitudes of the phase voltages also increase, which leads to an increase in the effective value of the voltage in the phases. In this case, the cosine dependence of the instantaneous voltage in the phases is distorted, without causing a change in the oscillation period. There is also a shift of the potential of the zero point of the load in the direction of increase by a certain amount.

\section{References.}

1. Salari, O., Hashtrudi Zaad, K., Bakhshai, A., \& Jain, P. (2018). Hybrid Energy Storage Systems for Electric Vehicles: Multi-Source Inverter Topologies. In $14^{\text {th }}$ International Conference on Power Electronics (CIEP), 24-26 Oct. 2018, Cholula, Mexico. https://doi.org/10.1109/CIEP.2018.8573377.

2. Neuburger, M., \& Haag, J. (2015). Photovoltaik im Elektrofahrzeug. Forschungsreport für die Elektrotechnik in Baden Württemberg 2014, 14-17. ISSN 2199-4889.

3. Pirienko, S., Neuburger, M., Ammann, U., Thrimawithana, D. J., Balakhontsev, A., \& Cheng, P.-W. (2018). Evaluation of the small-scale wind turbine converter's efficiency built with various types of semiconducting devices. In IEEE $3^{\text {rd }}$ International Conference on Intelligent Energy and Power Systems, 4, December 2018, (pp. 166-171). https://doi.org/10.1109/ IEPS.2018.8559517.

4. Beshta, A., Aziukovskyi, O., Balakhontsev, A., \& Shestakov, A. (2017). Combined power electronic converter for simultaneous operation of several renewable energy sources. In International Conference on Modern Electrical and Energy Systems (MEES), 28 June 2017, (pp. 236-239). Kremenchuk, Ukraine. https://doi.org/10.1109/MEES.2017.8248898.

5. Beshta, A., Sr., Balakhontsev, A., \& Khudolii, S. (2019). Performances of Asynchronous Motor within Variable Frequency Drive with Additional Power Source Plugged via Com- 
bined Converter. In $6^{\text {th }}$ IEEE International Conference on Energy Smart Systems, ESS 2019. 17-19 April 2019, (pp. 156-160). Kyiv; Ukraine. https://doi.org/10.1109/ESS.2019.8764192.

6. Beshta, O. O., Khudolii, S. S., Neuburger, M., \& Neuberger, N. (2019). Control of energy flows in electric drivetrain of electric vehicle with extra DC source. Naukovyi Visnyk Natsionalnoho Hirnychoho Universytetu, (2), 67-71. https://doi. org/10.29202/nvngu/2019-2/12.

7. Shchur, I., \& Biletskyi, Y. (2018). Battery Currents Limitation in Passivity Based Controlled Battery/Supercapacitor Hybrid Energy Storage System. Supercapacitor Hybrid Energy Storage System. In Proc. $38^{\text {th }}$ IEEE Int. Conf. on Electronics and Nanotechnology (ELNANO-2018), April 24-26, 2018, (pp. 504-510). Kyiv, Ukraine. https://doi.org/0.1109/ELNANO.2018.8477477.

8. Shchur, I., Rusek, A., \& Mandzyuk, M. (2015). Power effective work of PMSM in electric vehicles at the account of magnetic saturation and iron losses. Przeglad Elektrotechniczny (Electrical Review), (1), 199-202. https://doi.org/10.15199/48.2015.01.45.

9. Shapoval, I. A., Mykhalskyi, V. M., \& Doroshenko, A. L. (2017). Speed control of the doubly-fed induction machine with controlled converters in the stator and rotor circuits. Tekhnichna elektrodynamika, (6) 18-25. https://doi. org/10.15407/techned2017.06.018.

10. Mykhalskyi, V. M., Sobolev, V. M., Chopyk, V. V., \& Shapoval, I. A. (2018). Simulation of the electric power generation system on the basis of dfig with active filtering capabilities and reactive power compensation. Tekhnichna elektrodynamika, (5), 52-56. https://doi.org/10.15407/techned2018.05.052.

\section{Комплексне джерело електричної енергії для трифазного струму на основі автономного інвертора напруги}

\section{Г.Г. Півняк, О.О. Бешта}

Національний технічний університет «Дніпровська політехніка», м. Дніпро, Україна, e-mail: beshta.o.o@nmu.one

Мета. Обгрунтувати працездатність комбінованого джерела живлення асинхронного електропривода транспортного засобу, що складається із двох джерел живлення та одного автономного інвертора напруги, встановити режими роботи з використанням нульових комбінацій ключів інвертора та сформулювати умову передачі енергії електромеханічному перетворювачу від додаткового джерела живлення.

Методика. При проведенні досліджень роботи автономного інвертора напруги із двома джерелами живлення використовувалися методи математичного та імітаційного моделювання. Також застосовано метод порівняльного аналізу для вибору оптимального способу реалізації алгоритму керування та аналіз симетричної системи живлення.

Результати. Показана працездатність системи живлення асинхронного двигуна від одного автономного інвертора напруги із двома джерелами живлення. У роботі наведені математичні розрахунки побудови електромеханічної схеми, наведено модифікований алгоритм комутації ключів інвертора комбінованого джерела живлення, описані фізичні процеси.

Наукова новизна. Сформульовані умови передачі енергії до електромеханічного перетворювача від додаткового джерела живлення, що забезпечується вибором параметрів кола навантаження ЕРС додаткового джерела та збільшує складову напруги й навантажувальну здатність електромеханічного перетворювача.

Практична значимість. Спрощена електромеханічна схема асинхронного електропривода транспортного за- собу за рахунок комбінованого джерела живлення, що складається із двох джерел живлення та одного автономного інвертора напруги. Одне із джерел є додатковим джерелом, що підключене до електродвигуна через схему під'єднання до нульової точки статорних обмоток двигуна й «мінусового» терміналу автономного інвертора напруги, і включає DC-DC інвертор, діод, дросель і розрядний резистор.

Ключові слова: автономний інвертор напруги, джерела постійного струму, електропривод

\section{Комплексный источник электрической энергии для трехфазного тока на основе автономного инвертора напряжения}

\section{Г. Г. Пивняк, А. А. Бешта}

Национальный технический университет «Днепровская политехника», г. Днепр, Украина, e-mail: beshta.o.o@ nmu.one

Цель. Обосновать работоспособность комбинированного источника питания асинхронного электропривода транспортного средства, состоящего из двух источников питания и одного автономного инвертора напряжения, установить режимы работы с использованием нулевых комбинаций ключей инвертора и сформулировать условие передачи энергии электромеханическому преобразователю от дополнительного источника питания.

Методика. При проведении исследований работы автономного инвертора напряжения с двумя источниками питания использовались методы математического и имитационного моделирования. Также применен метод сравнительного анализа для выбора оптимального способа реализации алгоритма управления и анализ симметричной системы питания.

Результаты. Показана работоспособность системы питания асинхронного двигателя от одного автономного инвертора напряжения с двумя источниками питания. В работе приведены математические расчеты построения электромеханической схемы, приведен модифицированный алгоритм коммутации ключей инвертора комбинированного источника питания, описаны физические процессы.

Научная новизна. Сформулированы условия передачи энергии к электромеханическому преобразователю от дополнительного источника питания, которые обеспечиваются выбором параметров цепи нагрузки ЭДС дополнительного источника и увеличивают составляющую напряжения и нагрузочную способность электромеханического преобразователя.

Практическая значимость. Упрощена электромеханическая схема асинхронного электропривода транспортного средства за счет комбинированного источника питания, состоящего из двух источников питания и одного автономного инвертора напряжения. Один из источников является дополнительным источником, который подключен к электродвигателю через схему подключения к нулевой точке статорных обмоток двигателя и «минусового» терминала автономного инвертора напряжения, и включает DC-DC инвертор, диод, дроссель и разрядный резистор.

Ключевые слова: автономный инвертор напряжения, источники постоянного тока, электропривод

Recommended for publication by O.V.Sadovyi, Doctor of Technical Sciences. The manuscript was submitted 22.10.19. 